\title{
HABITAT AND SEASONAL DISTRIBUTION OF ODONATA (INSECTA) OF MULA AND MUtha RIVER BASINS, MAHARASHTRA, INDIA
}

\section{Aboli S. Kulkarni ${ }^{1} \&$ K.A. Subramanian ${ }^{2}$}

${ }^{1}$ Agharkar Research Institute, Gopal Ganesh Agarkar Road, Pune, Maharashtra 411004, India

${ }^{2}$ Zoological Survey of India, M-Block, New Alipore, Kolkata, West Bengal 700053, India

${ }^{1}$ aboli.kulkarni5@gmail.com, ${ }^{2}$ subbuka.zsi@gmail.com (corresponding author)

Abstract: Catchment landscape degradation and habitat modifications of freshwater ecosystems are a primary cause of biodiversity loss in riverine ecosystems all over the world. Many elements of the flora and fauna of freshwater ecosystems are sensitive to the changes in catchment land use and habitat modification. These sensitive taxa are also reliable indicators of freshwater ecosystem health. In the current study we investigate the seasonal and habitat distribution of Odonata (Insecta) across riparian land use types in Mula and Mutha river basins, northern Western Ghats, Maharashtra. There was a difference in the species composition across land use types and across seasons with highest diversity and abundance during the post monsoon period. The highest Odonata diversity was observed in urban areas followed by forest and agriculture fields. There was a loss of $31 \%$ of the odonate fauna in the study area over 50 years which could be due to rapid industrialization and urbanization of the region and consequent degradation of freshwater ecosystems. The significance of catchment land use on Odonata diversity and its value in landscape monitoring is discussed.

Keywords: Habitat use, local extinctions, northern Western Ghats, Odonata, seasonal distribution.

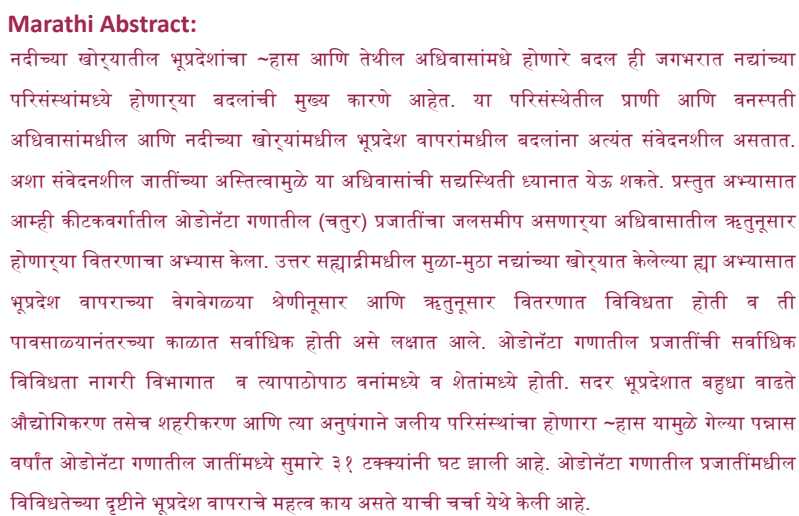

DOI: http://dx.doi.org/10.11609/JoTT.03253.4084-95| ZooBank: urn:Isid:zoobank.org:pub:05552EEE-692D-4AA8-AFAE-4E96AE123D93

Manuscript details: Ms \# 03253 | Received 14 July 2012 | Final received 19 March 2013 | Finally accepted 24 April 2013

Citation: Kulkarni, A.S. \& K.A. Subramanian (2013). Habitat and seasonal distribution of Odonata (Insecta) of Mula and Mutha river basins, Maharashtra, India. Journal of Threatened Taxa 5(7): 4084-4095; http://dx.doi.org/10.11609/JoTT.03253.4084-95

Copyright: (C) Kulkarni \& Subramanian 2013. Creative Commons Attribution 3.0 Unported License. JoTT allows unrestricted use of this article in any medium, reproduction and distribution by providing adequate credit to the authors and the source of publication.

Funding: Vinod Gadgil Smruti Pratishthan, Nashik, Maharashtra.

Competing Interest: None.

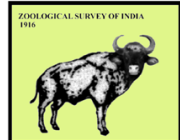

Acknowledgements: Aboli Kulkarni is grateful to "Vinod Gadgil Smruti Pratishthan, Nashik, Maharashtra" for providing funding assistance for this work and to Director, Zoological Survey of India and Officer-in-Charge Western Regional Centre for providing laboratory facilities to identify Odonata. She is also grateful to Dr. N.V. Joshi, CES, IISc, Bangalore for clearing basic concepts of statistical analysis, and to Dr. Ankur Patwardhan and Dr. Anand Padhye, Garware College, Pune for their encouragement and support. We also sincerely thank Col. Ashwin Baindur, College of Military Engineering, Pune for facilitating our studies in CME campus.

Author Contribution: AK did the field work, identified the odonata and analyzed the data. KAS designed the study, identified odonata, analyzed the data and wrote the manuscript.

Author Details: Ms. ABOLI KULKARNI is a post graduate student of biodiversity and this work is a part of her MSc Thesis. Currently, she is working on documentation of flora and fauna of Sacred Groves from Pune District at Agharkar Research Institute, Pune. She is deeply interested in studying Habitat Ecology and habitat preferences of organisms.

DR. K.A. SUBRAMANIAN is scientist at Zoological Survey of India, Kolkata. Currently he is working on the diversity and distribution of Odonata, Ephemeroptera and Plecoptera of India. 


\section{INTRODUCTION}

Around the world, freshwater habitats are being subjected to increased levels of human disturbance (Saunders et al. 2002). An assessment of the status of inland water ecosystems shows that globally, the most threatened river catchments are found in the Indian subcontinent (WCMC 2000; Subramanian 2010; Subramanian et al. 2011). Healthy riverine ecosystems are vital for ecological integrity of the landscape. However, anthropogenic modifications such as the construction of dams, draining of streams, agricultural expansion, urban and industrial pollution and riparian deforestation have resulted in degradation of aquatic ecosystems and loss of freshwater biodiversity all over the world, especially in tropical Asia and including the Western Ghats (Dudgeon 1994, 2000; Subramanian, 2010; Molur et al. 2011). Such activity influences natural resources, hydrology, nutrient cycle and natural habitat over time and space, changes which in turn reduce the biodiversity of a region. Some modifications result in loss of certain species which are sensitive to habitat changes while promoting colonization by generalized widespread species which can tolerate the changed conditions. A detailed review of biodiversity and threats to riverine ecosystems of the Western Ghats (Subramanian 2010; Molur et al. 2011) highlights the impact of anthropogenic modifications to the riparian zones in terms of depleting fresh water biodiversity of the region. These reviews emphasis the need for long term catchment scale conservation strategies for the freshwater biodiversity of the Western Ghats.. These strategies are directly dependant upon detailed documentation of biodiversity at various spatiotemporal scales and development of suitable indicators for long term monitoring. The indicator approach was followed using aquatic macroinvertebrates such as dragonflies and damselflies (Odonata), Coleoptera and Mollusca to identify, monitor and conserve freshwater ecosystems in South Africa and United Kingdom. These studies have shown that Odonata are reliable indicators for freshwater ecosystem health (Samways 1992, 1993, 1995; Clark \& Samways 1996; Painter 1999). Odonata forms an important tool for various types of assessments and monitoring such as measure of biodiversity, wetland health and integrity, biological impact of climate change etc (Ortelli 2008).

The odonate fauna of the Western Ghats is diverse with 176 species, 68 of which are endemic (Subramanian 2009; Subramanian et al. 2008, 2011). Many species are very specific to particular breeding habitat and adults are usually found close to these. This habitat specificity of species makes them an ideal candidate to assess and monitor ecosystem health.

The rich diversity and habitat specificity of Odonata of India provide a unique opportunity to develop tools for assessing freshwater ecosystem health. An earlier study conducted in Uttara Kannada District, Karnataka has shown that there is a clear relationship between Odonata diversity and riparian land use (Subramanian 2008). The Odonata of Pune District was documented by various workers since the beginning of the $20^{\text {th }}$ century (Fraser 1933-36; Prasad 1996). These studies were mostly species checklists and details of habitat and season distribution were not available. Pune is one of the most industrialized and urbanized landscapes of the subcontinent with rapid changes in land use. The freshwater ecosystems of the region are highly stressed due to pollution and habitat alteration. The river basins of the region are heavily deforested and also have the highest density of dams in the Western Ghats (Subramanian 2010). A study on diversity and distribution pattern of odonates in such highly impacted landscapes will help in understanding ongoing ecological processes in shaping species communities and identifying factors driving local species loss. The present study aims to document habitat and seasonal distribution of Odonata in the Mula-Mutha river basins, major tributaries of the Bhima River which eventually drains into the Krishna basin.

\section{MATERIALS AND METHODS}

\section{Study Area}

The study was carried out in the Mula-Mutha river basins between Tamhini Reserve Forest $\left(18.460^{\circ} \mathrm{N} \&\right.$ $\left.73.414^{\circ} \mathrm{E}\right)$ and Ujani Wetland $\left(18.299^{\circ} \mathrm{N} \& 74.763^{\circ} \mathrm{E}\right)$ in Pune District, Maharashtra State during May 2010 to April 2011. It covers an area of approximately $150 \mathrm{~km}^{2}$ (Image 1). There is a clear altitude and rainfall gradient from west to east in the study area (Table 1 ). The Tamhini Reserve Forest in the Western Ghats is at a higher elevation and receives more rainfall than the Ujani Wetland in the east.

The study area includes various habitats such as semi evergreen forest, agricultural land, urban-industrial area (Pune City), natural and manmade wetlands. Study sites were selected in three predominant land use types viz., forest, agriculture and urban (Images 2-7). In forested landscapes, we sampled streams with forest cover. The important stream habitats were cascades, riffles, small waterfalls and pools. Paddy and sugarcane dominate the 

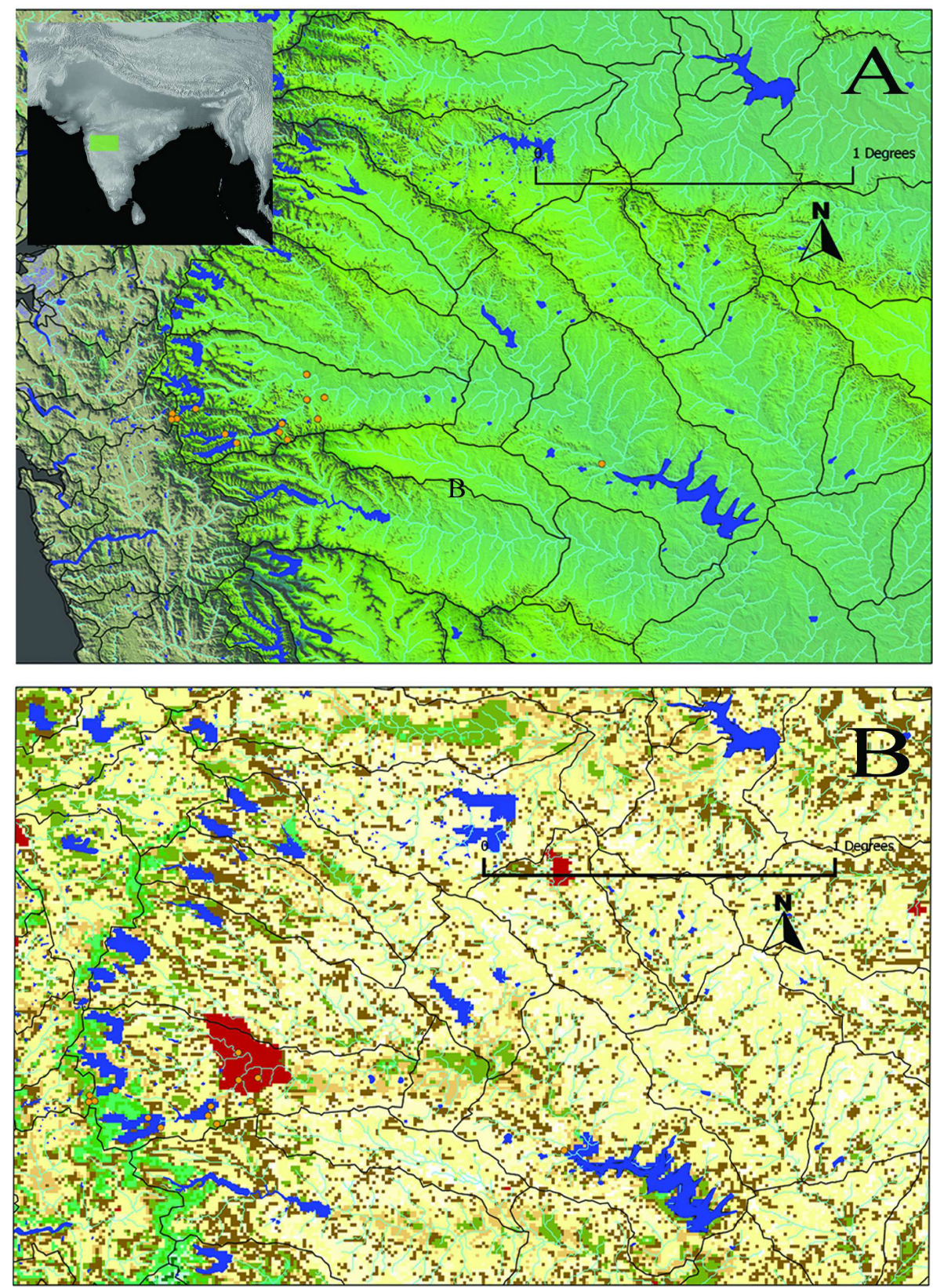

Image 1. Inset: Location of the study area (highlighted green) (A) Physiography of study area with streams and dams. Sampling localities are marked orange (B) Current landuse pattern of the study area. Light and dark green cells are forests/tree covered areas. Red cells are urban/ industrial areas. Blue cells are water bodies. Brown, light brown and cream coloured cells are agricultural fields. Orange spots are study sites.

agricultural landscapes. This land use type is scattered throughout the study area from west to east. The urban zone is largely located between forest and agriculture landscape to the west and agriculture landscape to the east and we sampled dams, rivers, garden ponds and lakes in this region.

\section{Sampling Methods}

Adult odonates were sampled in 12 sampling localities (Table 1). The sampling was carried out using a belt transect of 500×10 m for one and half hour in the study sites between 0900 to 1300 hrs when their activity was at its peak. Field sampling was done during the premonsoon (May-June) and postmonsoon (AugustOctober) periods and winter (November-February) during May 2009 to February 2010. Each transect was traversed on foot and all the adult dragonflies observed within $5 \mathrm{~m}$ of transect line were identified and counted. Common species were identified, photographed in the field (Appendix 1) and unidentified ones were collected 
Table 1. Details of study localities

\begin{tabular}{|c|c|c|c|c|c|c|}
\hline Locality & Land use type & Latitude & Longitude & Altitude $(\mathrm{m})$ & $\begin{array}{l}\text { Annual Mean } \\
\text { Temp }\left({ }^{\circ} \mathrm{C}\right)\end{array}$ & $\begin{array}{l}\text { Annual Mean } \\
\text { Rainfall }(\mathrm{mm})\end{array}$ \\
\hline Bhigwan & Agricultural & 18.2995 & 74.7639 & 507 & 26 & 517 \\
\hline Empress Garden & Urban & 18.5121 & 73.8923 & 567 & 25 & 702 \\
\hline $\begin{array}{l}\text { College of Military } \\
\text { Engineering (CME) }\end{array}$ & Urban & 18.5864 & 73.8363 & 573 & 25 & 766 \\
\hline Mutha River & Urban & 18.5057 & 73.837 & 560 & 25 & 768 \\
\hline Katraj Tekdi & Urban & 18.4433 & 73.8712 & 693 & 24 & 920 \\
\hline Khadakwasla & Urban & 18.4283 & 73.7584 & 605 & 25 & 1128 \\
\hline Sinhagad Valley & Agricultural & 18.3766 & 73.7759 & 735 & 24 & 1308 \\
\hline Stream 1 & Forest & 18.4762 & 73.4877 & 723 & 24 & 3026 \\
\hline Paddy field 1 & Agricultural & 18.444 & 73.4289 & 780 & 23 & 3371 \\
\hline Stream 2 & Forest & 18.4442 & 73.4288 & 780 & 23 & 3371 \\
\hline Stream 3 & Forest & 18.4416 & 73.4116 & 408 & 25 & 3745 \\
\hline Stream 4 & Forest & 18.4606 & 73.414 & 379 & 25 & 3825 \\
\hline
\end{tabular}
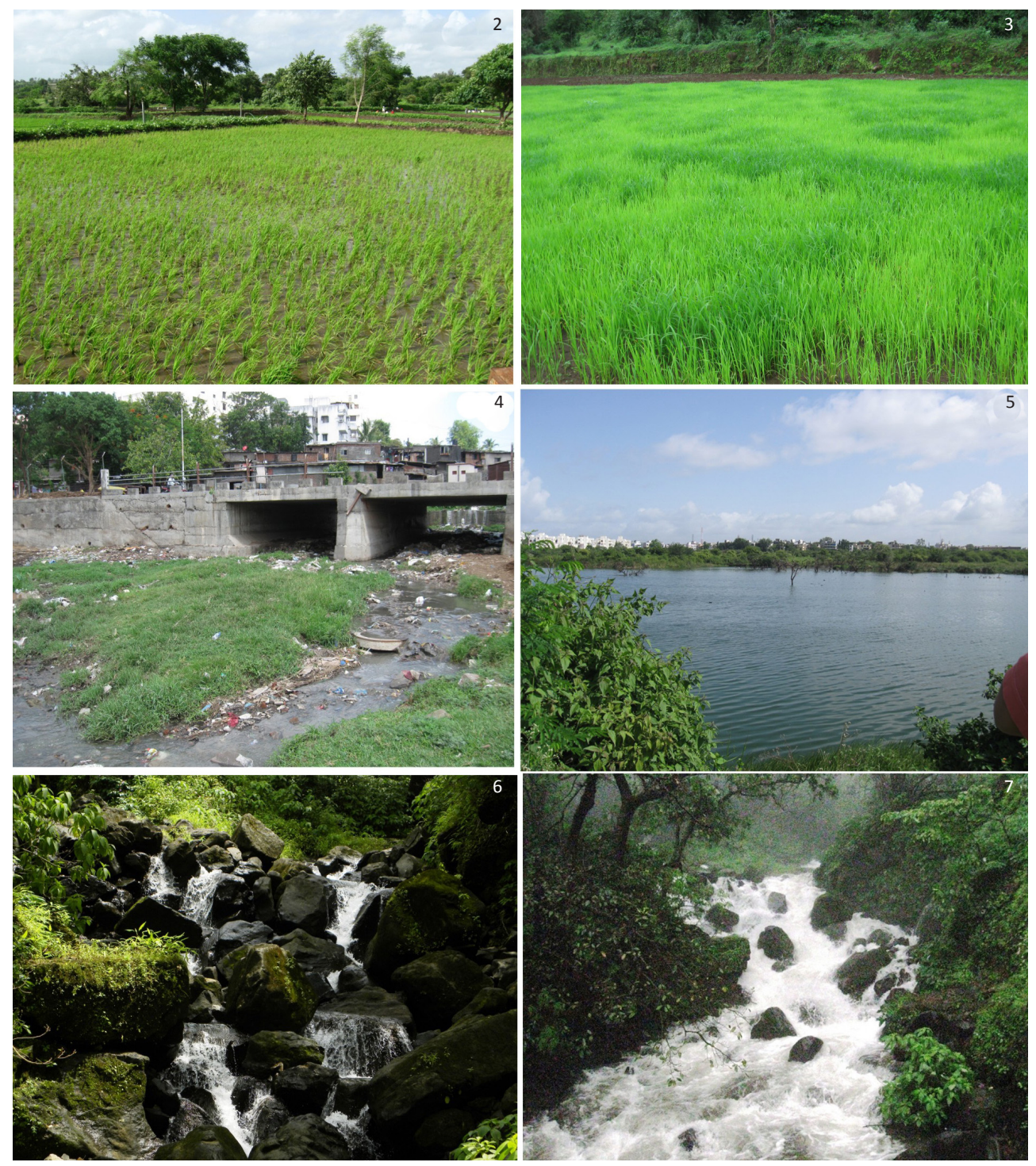

Images 2-7. Sampling sites in the study area showing different land use types. $2 \& 3$ - Paddy fields of Tamhini Village, Pune; 4 - A view of the Mutha River, Pune;

5 - A view of College of Military Engineering Lake; 6\&7 - A stream from Tamhini Ghat, Pune c Aboli Kulkarni 
using a butterfly net and identified in the laboratory using taxonomic literature and field identification guides (Fraser 1933-1936; Subramanian 2009).

\section{Habitat Assessment}

Habitat quality was assessed during sampling. The following observations were made for each of the transect: availability of perching sites, presence of emergent aquatic vegetation, human disturbance such as domestic sewage, industrial effluent, solid waste, check dams, canalization, riparian deforestation, flow modification, agricultural runoff, and soil erosion. Based on these observations each site was ranked for a disturbance score ranging from 1-10, 1 being the lowest and 10 the highest.

\section{Data Analysis}

The input for the data analysis was a relative abundance matrix of family, genera and species across sites, land use types and seasons. Abundance data were log transformed to study relative abundance across seasons in different land use types. Diversity indices were calculated using the software PAST (Hammer et al. 2001).

\section{RESULTS}

\section{Species Abundance}

A total of 609 individuals belonging to 46 species in 26 genera and eight families was recorded during the study period (Table 2 ). The most dominant species was Pantala flavescens (Fabricius, 1798) which accounted for $23 \%$ of total number of individuals found during sampling. This dominance could be due to mass emergence of the species after monsoon and their yearly aggregation before migration. Individuals of this species congregate every year before migration to Eastern Africa (Anderson 2009). This was followed by Brachythemis contaminata (Fabricius, 1793) with $17 \%$ individuals found only in urban and agricultural landscapes except a single record from one of the streams in a forest area. Brachythemis contaminata is a dragonfly of polluted water, which was seen abundantly where sewage is discharged. Interestingly, this species was observed in one stream which is located near Mulshi Lake during one of the postmonsoon surveys. This stream near Mulshi Lake being a picnic spot attracts tourists during the monsoon and post-monsoon season resulting in pollution of streams with organic waste. The species was recorded only when the stream was polluted in post-monsoon.
The third most abundant species was Trithemis festiva (Rambur, 1842) with $11 \%$ of individuals that were recorded mostly from forested areas except a single record from one garden pond in an urban area. Trithemis festiva is known to breed in sluggish streams and usually perches on boulders and aquatic plants. This is a common species in the streams of northern Western Ghats.

Species such as Diplacodes trivialis (Rambur, 1842), Orthetrum sabina (Drury, 1770), Trithemis aurora (Burmeister, 1839), Rhodischnura nursei (Morton, 1907) were locally abundant in some of the study areas with less than 50 individuals in overall study area. Whereas species such as Vestalis apicalis (Rambur, 1842), Ceriagrion olivaceum (Laidlaw, 1916), Pseudagrion decorum (Rambur, 1842) were recorded only once (Fig 2).

Species such as Paragomphus lineatus Selys, 1850, Acisoma panorpoides Rambur, 1842, Gynacantha dravida Lieftinck, 1960, Gynacantha bayadera Selys, 1854, Tholymis tillagra Fabricius, 1798, Orthetrum chrysis Selys, 1891, Copera marginipes Rambur, 1842 and Neurothemis intermedia Rambur, 1842 were recorded from the sampling area but they were not encountered during transect counts. This could be due to their relative rarity or crepuscular flight activity.

\section{Species Diversity and Community Composition}

Forest Landscapes: In forest streams a total of 21 species and 185 individuals were recorded. Trithemis festiva (Rambur, 1842) was the dominant species with 66 individuals followed by Pantala flavescens (Fabricius, 1798) and Trithemis aurora (Burmeister, 1839) with 33 and 16 individuals respectively. Species such as Vestalis gracilis (Rambur, 1842), Disparoneura quadrimaculata (Rambur, 1842) which usually occur in forested areas were also recorded. Rhinocypha bisignata (Selys 1853), Vestalis apicalis (Selys 1873), Microgomphus torquatus (Selys, 1854), Neurothemis fulvia (Drury, 1773) were recorded only once from a single stream. Disparoneura quadrimaculata, Vestalis apicalis, Vestalis gracilis, Neurothemis fulvia are known to breed in streams and their geographic restrictedness in the study area is due to the availability of suitable breeding habitat. Vestalis gracilis, Vestalis apicalis and Rhinocypha bisignata were observed from only two streams where canopy cover is greater than $50 \%$. It was observed that the abundance of these species were very low when compared with other species found in forested streams and restricted to shaded areas of the stream. Another interesting observation was presence of Microgomphus torquatus 
Table 2. Seasonal abundance of Odonata across land use types.

\begin{tabular}{|c|c|c|c|c|c|c|c|c|c|c|c|}
\hline & \multirow[b]{3}{*}{ Species } & \multicolumn{9}{|c|}{ Season } & \multirow[b]{3}{*}{ Total } \\
\hline & & \multicolumn{3}{|c|}{ Pre monsoon } & \multicolumn{3}{|c|}{ Post monsoon } & \multicolumn{3}{|c|}{ Winter } & \\
\hline & & AG & FO & UR & AG & FO & UR & AG & FO & UR & \\
\hline 1 & Vestalis apicalis & 0 & 1 & 0 & 0 & 0 & 0 & 0 & 0 & 0 & 1 \\
\hline 2 & Vestalis gracilis & 0 & 0 & 0 & 0 & 1 & 0 & 0 & 2 & 0 & 3 \\
\hline 3 & Agriocnemis pygmea & 0 & 0 & 0 & 0 & 0 & 0 & 5 & 0 & 4 & 9 \\
\hline 4 & Ceriagrion coromandelianum & 0 & 0 & 0 & 1 & 0 & 3 & 0 & 0 & 2 & 6 \\
\hline 5 & Ceriagrion olivaceum & 0 & 0 & 1 & 0 & 0 & 0 & 0 & 1 & 0 & 2 \\
\hline 6 & Coenagrion dyeri & 0 & 0 & 0 & 0 & 0 & 0 & 2 & 0 & 0 & 2 \\
\hline 7 & Ischnura aurora & 0 & 0 & 2 & 0 & 2 & 2 & 0 & 0 & 2 & 8 \\
\hline 8 & Ischnura senegalensis & 0 & 0 & 0 & 0 & 0 & 6 & 0 & 0 & 8 & 14 \\
\hline 9 & Pseudagrion decorum & 0 & 0 & 0 & 0 & 0 & 1 & 0 & 0 & 0 & 1 \\
\hline 10 & Pseudagrion indicum & 0 & 0 & 0 & 0 & 1 & 0 & 0 & 0 & 0 & 1 \\
\hline 11 & Pseudagrion microcephalum & 1 & 0 & 0 & 0 & 0 & 8 & 0 & 0 & 0 & 9 \\
\hline 12 & Pseudagrion rubriceps & 0 & 0 & 0 & 0 & 0 & 5 & 0 & 0 & 16 & 21 \\
\hline 13 & Rhodischnura nursei & 0 & 0 & 0 & 0 & 0 & 0 & 9 & 0 & 0 & 9 \\
\hline 14 & Lestes elatus & 0 & 0 & 0 & 2 & 0 & 0 & 0 & 0 & 0 & 2 \\
\hline 15 & Disparoneura quadrimaculata & 0 & 3 & 0 & 1 & 12 & 0 & 0 & 0 & 0 & 16 \\
\hline 16 & Anax immaculifrons & 0 & 4 & 0 & 0 & 3 & 5 & 0 & 0 & 4 & 16 \\
\hline 17 & Ictinogomphus rapax & 0 & 0 & 0 & 0 & 0 & 7 & 0 & 0 & 0 & 7 \\
\hline 18 & Microgomphus torquatus & 0 & 1 & 0 & 0 & 0 & 1 & 0 & 0 & 0 & 2 \\
\hline 19 & Brachydiplax sorbina & 1 & 0 & 0 & 0 & 0 & 1 & 0 & 0 & 0 & 2 \\
\hline 20 & Brachythemis contaminata & 24 & 0 & 2 & 1 & 2 & 70 & 2 & 0 & 19 & 120 \\
\hline 21 & Bradinopyga geminata & 0 & 0 & 3 & 0 & 0 & 0 & 0 & 2 & 0 & 5 \\
\hline 22 & Crocothemis servilia & 0 & 0 & 1 & 2 & 0 & 3 & 0 & 2 & 0 & 8 \\
\hline 23 & Diplacodes trivialis & 0 & 1 & 3 & 6 & 3 & 5 & 6 & 2 & 0 & 26 \\
\hline 24 & Neurothemis fulvia & 0 & 0 & 0 & 0 & 2 & 0 & 0 & 0 & 0 & 2 \\
\hline 25 & Orthetrum chrysostigma & 0 & 0 & 0 & 0 & 0 & 1 & 0 & 0 & 0 & 1 \\
\hline 26 & Orthetrum glaucum & 0 & 0 & 0 & 0 & 0 & 1 & 0 & 2 & 0 & 3 \\
\hline 27 & Orthetrum Iuzonicum & 0 & 0 & 0 & 0 & 0 & 0 & 3 & 0 & 0 & 3 \\
\hline 28 & Orthetrum pruinosum & 0 & 0 & 0 & 0 & 2 & 4 & 1 & 7 & 2 & 16 \\
\hline 29 & Orthetrum sabina & 0 & 0 & 1 & 2 & 0 & 20 & 0 & 0 & 10 & 33 \\
\hline 30 & Orthetrum taeniolatum & 0 & 0 & 0 & 1 & 2 & 2 & 0 & 4 & 1 & 10 \\
\hline 31 & Pantala flavescens & 0 & 1 & 0 & 49 & 31 & 55 & 4 & 2 & 0 & 142 \\
\hline 32 & Potamarcha congener & 0 & 0 & 0 & 0 & 0 & 0 & 4 & 0 & 0 & 4 \\
\hline 33 & Rhinocypha bisignata & 0 & 0 & 0 & 0 & 1 & 0 & 0 & 0 & 0 & 1 \\
\hline 34 & Rhyothemis variegata & 0 & 0 & 1 & 0 & 0 & 14 & 0 & 0 & 0 & 15 \\
\hline 35 & Sympetrum fonscolumbi & 0 & 0 & 0 & 0 & 0 & 2 & 0 & 0 & 0 & 2 \\
\hline 36 & Tramea basiliaris & 0 & 0 & 0 & 1 & 0 & 9 & 0 & 0 & 0 & 10 \\
\hline 37 & Trithemis aurora & 0 & 1 & 4 & 0 & 5 & 13 & 0 & 10 & 3 & 36 \\
\hline 38 & Trithemis festiva & 0 & 2 & 0 & 6 & 47 & 1 & 0 & 27 & 1 & 84 \\
\hline 39 & Trithemis kirbyi & 0 & 0 & 0 & 0 & 1 & 0 & 0 & 2 & 0 & 3 \\
\hline 40 & Trithemis pallidinervis & 2 & 0 & 0 & 0 & 0 & 4 & 0 & 0 & 0 & 6 \\
\hline & Grand Total & 28 & 14 & 18 & 72 & 115 & 243 & 36 & 63 & 72 & 661 \\
\hline
\end{tabular}

Legend: AG - Agriculture; FO - Forest; UR - Urban 
(Selys, 1854). This species was originally described by Fraser from the Mula River in Pune in 1933. Currently this species was not encountered within the urban limits and now restricted to upper forested catchments of study area. This clearly indicates the change in habitat of the riverine ecosystem of the region.

Of the eight families which were recorded from the entire study area, species belonging to seven families were recorded from forest streams. The family richness was highest in forest streams; however they were represented by fewer species. This high family richness was observed only during post-monsoon season. Libellulidae was the most abundant family due to presence of common wide-spread species such as Trithemis festiva, Orthetrum pruinosum and Orthetrum taeniolatum. It was followed by Aeshnidae and Protoneuridae. The families Calopterigidae, Chlorocyphidae, Gomphidae were all represented by fewer than five individuals.

Agricultural Landscapes: In agricultural area, a total of 19 species and 137 individuals were recorded from four sites. Agricultural land was also dominated by Pantala flavescens, which accounted for $40 \%$ individuals followed by Brachythemis contaminata (20\%) and Diplacodes trivialis (9\%). The remainder of species found in agricultural landscapes were of low abundance with fewer than 10 individuals. The species Potamarcha congener (Rambur, 1842) and Coenagrion dyeri (Fraser, 1924) were recorded only from one paddy field. Trithemis palidinervis was recorded only during the pre-monsoon period. Lestes elatus was recorded during post-monsoon surveys from paddy fields of Sinhagad Valley and large congregation was seen during winter on the hill tops of Singhagad Valley. Rhodischnura nursei was recorded during winter only from Bhigwan located in the eastern part of the study area. This species is confined to semiarid zones of northwestern India (Fraser 1933) and usually seen during September to November. However, nine individuals of this species were recorded from Bhigwan in January. Another species which was recorded only from Bhigwan is Coenagrion dyeri. This species is widely distributed in peninsular India and known to breed in stagnant and weedy ponds and is often seen perching flat on floating aquatic plants.

Urban Landscapes: A total of 287 individuals belonging to 32 species was recorded from urban areas. Brachythemis contaminata (Fabricius, 1793) was the dominant species with $25 \%$ of individuals followed by Pantala flavescens and Orthetrum sabina with $19 \%$ and $7 \%$ of individuals respectively. Species such as Orthetrum glaucum (Brauer, 1865) and Pseudagrion decorum (Rambur, 1842) were recorded only once. The species such as Rhyothemis variegata and Pseudagrion rubriceps were recorded only from the College of Military Engineering (CME) Lake and Tramea basiliaris was observed from Katraj Hill and from one of the paddy fields from Tamhini Village. Across three land use types, there was a difference between the species composition and, in terms of species richness, urban habitats were the most diverse followed by forest and agricultural land. Simpson, Fisher's alpha and Margalef indices all show the same relationship (Table 3).

\section{Seasonality}

Species diversity and abundance varied across seasons with post-monsoon being highest in species diversity as well as abundance. Many species have their flight period during the post monsoon season and a high diversity of odonates during this season could be attributed to this. During the post-monsoon, 12 species from agricultural land, 16 species from forest streams and 28 species from urban habitats were recorded. The species Pantala flavescens, Trithemis festiva and Brachythemis contaminata dominated all land use types.

The pre-monsoon season had the lowest species diversity and abundance. During this season, a total of four, eight and nine species were recorded from agriculture, forest and urban areas, respectively. Brachythemis contaminata, Anax immaculifrons and Trithemis aurora dominated urban, forest and agriculture landscapes, respectively during this season.

During winter, nine, 12 and 13 species were recorded from agriculture, forest and urban areas, respectively. The species Rhodischnura nursei, Trithemis festiva,

Table 3. Diversity indices for different land use types

\begin{tabular}{|l|c|c|c|c|c|}
\hline Landuse type & No of species & No of individuals & Simpson (1-D) & Fisher's alpha & Margalef \\
\hline Agriculture & 19 & 137 & 0.782 & 5.988 & 3.659 \\
\hline Forest & 21 & 185 & 0.8179 & 6.095 & 3.831 \\
\hline Urban & 32 & 287 & 0.8779 & 9.224 & 5.478 \\
\hline
\end{tabular}


Brachythemis contaminanta dominated agricultural, forest and urban landscapes, respectively during this season.

\section{Species Turnover}

Species turnover across land use types as measured by Jaccard's index shows that urban and agricultural areas have similar Odonata communities and they share about $38 \%$ of species. The odonate communities of forest streams were distinct and they shared only 25 and 32 percent of odonate species with agricultural and urban landscapes, respectively (Table 4). The distinctiveness of forest stream odonate communities was due to the presence of families such as Calopterygidae, Chlorocyphidae and Protoneuridae as represented by Vestalis gracilis, V. apicalis, Rhinocypha bisignata and Disparoneura quadrimaculata, respectively. There were 11 species which were observed from both urban and agricultural areas. Those species shared between agricultural and urban land use types are common widespread species breeding in a wide spectrum of wetland habitats. These landscapes are also undergoing similar human induced habitat modifications due to disturbance.

Disturbance scores of study localities and species diversity shows that there is no clear relationship between species diversity and disturbance (Table 5). Study sites with high disturbance scores such as the Mutha River also have high species diversity. Conversely, sites with low disturbance scores (e.g., Stream-4) reported low
Table 4. Jaccard's Index of similarlity for land use types

\begin{tabular}{|l|c|c|c|}
\hline & Agriculture & Forest & Urban \\
\hline Agriculture & 1 & 0.25 & 0.37838 \\
\hline Forest & 0.25 & 1 & 0.325 \\
\hline Urban & 0.37838 & 0.325 & 1 \\
\hline
\end{tabular}

species diversity. High diversity in some of the degraded areas are due to presence of common widespread species with tolerance of disturbance and pollution. This shows that in this landscape over all, species diversity per se is not a good indicator for assessment of wetland ecosystem health. Presence/absence of habitat specialist species should be taken into consideration for monitoring wetland ecosystem health.

\section{DISCUSSION}

Fraser documented the fauna of Pune region while surveying the Odonata fauna of western India (Fraser 1924, 1932, 1933-36). Subsequently, Prasad (1996) also documented the odonate fauna of the region. These studies recorded 70 species of odonates from Pune (Appendix 2). Our current study and another in the region conducted over two years (Subramanian \& Talmale 2010) recorded 46 species from transects and eight species outside transects. The remaining 22 species were not recorded even after repeated searching. Many

Table 5. Disturbance score matrix for study localities

\begin{tabular}{|c|c|c|c|c|c|c|c|c|c|c|c|c|c|c|c|}
\hline Locality & A & B & C & D & $\mathrm{E}$ & $F$ & G & $\mathbf{H}$ & 1 & J & K & $\mathbf{L}$ & M & $\mathbf{N}$ & $\begin{array}{c}\text { Average } \\
\text { Disturbance Score }\end{array}$ \\
\hline Mutha River & 17 & 0 & 9 & 10 & 10 & 10 & 10 & 0 & 10 & 4 & 6 & 0 & 10 & 7 & 6.62 \\
\hline Bhigwan & 8 & 0 & 8 & 8 & 10 & 10 & 10 & 0 & 0 & 5 & 4 & 10 & 10 & 6 & 6.23 \\
\hline Khadakwasla & 13 & 0 & 9 & 7 & 6 & 4 & 6 & 10 & 7 & 6 & 10 & 4 & 5 & 7 & 6.23 \\
\hline Sinhagad valley & 7 & 0 & 0 & 0 & 4 & 4 & 2 & 10 & 5 & 4 & 10 & 6 & 6 & 5 & 4.31 \\
\hline Empress Garden & 12 & 3 & 5 & 0 & 4 & 0 & 1 & 7 & 10 & 2 & 9 & 0 & 2 & 1 & 3.38 \\
\hline CME & 18 & 3 & 7 & 7 & 0 & 0 & 0 & 6 & 8 & 2 & 7 & 0 & 2 & 1 & 3.31 \\
\hline Stream 2 & 10 & 1 & 7 & 0 & 5 & 0 & 2 & 5 & 0 & 4 & 6 & 0 & 4 & 5 & 3.00 \\
\hline Katraj tekdi & 9 & 0 & 2 & 0 & 7 & 0 & 1 & 7 & 0 & 4 & 0 & 0 & 2 & 4 & 2.08 \\
\hline Stream 1 & 7 & 1 & 5 & 4 & 3 & 0 & 3 & 0 & 0 & 4 & 0 & 0 & 2 & 1 & 1.77 \\
\hline Stream 3 & 14 & 6 & 9 & 0 & 0 & 0 & 0 & 0 & 0 & 6 & 0 & 0 & 0 & 1 & 1.69 \\
\hline Stream 4 & 6 & 9 & 9 & 0 & 0 & 0 & 0 & 0 & 0 & 0 & 0 & 0 & 0 & 1 & 1.46 \\
\hline Paddy field 1 & 9 & 0 & 1 & 0 & 0 & 0 & 0 & 0 & 0 & 0 & 0 & 5 & 1 & 1 & 0.62 \\
\hline
\end{tabular}

Legend: (A) Species Richness (B) Shade Cover (C) Perching site availability (D) Emergent Aquatic Vegetation (E) Domestic Sewage (F) Industrial effluent (G) Solid waste (H) Check dams (I) Canalization (J) Riparian deforestation (K) Flow modification (L) Agricultural runoff (M) Water pollution (N) Soil Erosion 
of these species such as Anaciaeschna jaspidea, Anax guttatus, Epopthalmia vittata, Hemianax ephippiger and Macromia cingulata, can still be found in nearby less disturbed areas such as Lonavala-Khandala, Karjat, Karad, etc. However, species such as Burmagomphus pyramidalis, Cyclogomphus heterostylus, Cyclogomphus vesiculosus, Cyclogomphus ypsilon and Cyclogomphus wilkinsi, have not been recorded from Pune for a long time. These species are also not represented in the National Zoological Collection, Western Regional Centre, Zoological Survey of India, Pune which has been collecting odonates from the region for the past 50 years. This indicates that these species have become locally extinct or have reached such low levels of population that they cannot be detected by our sampling protocols.

The loss of $31 \%$ of odonates from this region is alarming. Many species not recorded such as Burmagomphuspyramidalis, Cyclogomphusheterostylus, Cyclogomphus ypsilon and Cyclogomphus wilkinsi, breed in and are closely associated with unpolluted rivers and streams. In the last 50 years, the riverine ecosystems of the region have been drastically altered. Seventeen dams currently exist in this region supplying water for irrigation, housing, industry and power generation. This catastrophic landscape and riverine ecosystem alteration over the years almost certainly depauperated the odonate fauna. In agreement with our findings, remarkably similar results are also reported for the fish fauna of Mula and Mutha rivers, where $30 \%$ of fish fauna was reported to be lost in the past 60 years (Wagh \& Ghate 2002). These results strongly indicate that landscape and riverine ecosystem level impacts could have affected other freshwater biodiversity elements, which need further investigation.

Our study shows that species turnover and abundance vary across seasons and land use types in the study region. It is evident from this study that there is strong habitat and land use association and seasonality in species richness which is responsible for shaping the odonate community of the region. Loss of regional odonate diversity could be attributed to major changes in freshwater ecosystems, habitat loss and degradation of quality of available habitats of the region. These changes could have also had an effect on other freshwater biodiversity elements and a cascading effect on terrestrial biodiversity. This link needs further study.

This result has important implications for developing long term biomonitoring tools using odonates as surrogates. Seasonal and landscape variations in species diversity needs to be taken into account while designing any landscape level biodiversity monitoring programmes.
Our study also emphasizes the importance of urban green spaces with wetlands in conserving regional Odonata fauna. High diversity and abundance in urban areas was mainly due to the CME campus where there is a network of man made lakes and natural or semi-natural vegetation with minimal disturbance. Such habitats are not only refugia for odonates but also for other flora and fauna. Hitherto about 25 species of trees, many species of herbs, aquatic plants, butterflies, and 112 species of birds including migrants have been recorded from CME campus. Moreover, the lakes of the CME are important wintering grounds for a large number of resident and migratory water birds. Such green patches in the highly industrialized and polluted landscape of the Pune region provide much needed refugiae for the biodiversity. Similar refugiae need to be identified in other urban centres in India and long term protection needs to be provided for conserving regional biodiversity.

\section{REFERENCES}

Alex Cordoba-Anguilar (ed.) (2008). Dragonflies and Damselflies for Ecological and Evolutionary Research, Oxford University Press, Oxford, 290pp.

Anderson, R.C. (2009). Do dragonflies migrate across the western Indian Ocean? Journal of Tropical Ecology 25: 347-348; http:// dx.doi.org/10.1017/S0266467409006087

Dudgeon, D. (1994). Research strategies for the conservation and management of tropical Asian streams and rivers. International Journal of Ecology and Environment 20: 255-285.

Dudgeon, D. (2000). The Ecology of tropical Asian rivers and streams in relation to biodiversity conservation. Annual Review of Ecology and Systematics 31: 239-263.

Fraser, F.C. (1924). A Survey of the Odonate (Dragonfly) Fauna of Western India with Special Remarks on the Genera Macromia and Idionyx and Descriptions of Thirty New Species with Appendices I \& II. Records of The Indian Museum (A Journal Of Indian Zoology). 26(5): 423-522.

Fraser, F.C. (1932). Additions to the survey of odonate fauna of Western India, with descriptions of nine new species. Records of the Indian Museum 32: 443-474.

Fraser, F.C. (1933). The Fauna of British India including Ceylon and Burma. Odonata Vol. I. Taylor and Francis Ltd., London, 423pp.

Fraser, F.C. (1934). The Fauna of British India including Ceylon and Burma. Odonata Vol. II. Taylor and Francis Ltd., London, 398pp.

Fraser, F.C. (1936). The Fauna of British India including Ceylon and Burma. Odonata Vol. III. Taylor and Francis Ltd., London, 461pp

Hammer, O., D.A.T. Harper \& P.D. Ryan (2001). PAST: Paleontological Statistics Software Package for Education and Data Analysis. Palaeontologia Electronica 4(1): 9pp. <http://palaeoelectronica. org/2001_1/past/issue1_01.htm>. Accessed 15 May 2012.

Molur, S., K.G. Smith, B.A. Daniel \& W.R.T. Darwall (Compilers) (2011). The Status and Distribution of Freshwater Biodversity in the Western Ghats, India. IUCN, Cambridge, UK and Glad, Switzerland and Zoo Outreach Organization, Coimbatore, India, 116pp.

Painter, D. (1999). Macroinvertebrate distributions and the conservation value of aquatic Coleoptera, Mollusca and Odonata in the ditches of traditionally managed and grazing fen at Wicken Fen, UK. Journal of Applied Ecology 36: 33-48; http://dx.doi. org/10.1046/j.1365-2664.1999.00376.x 

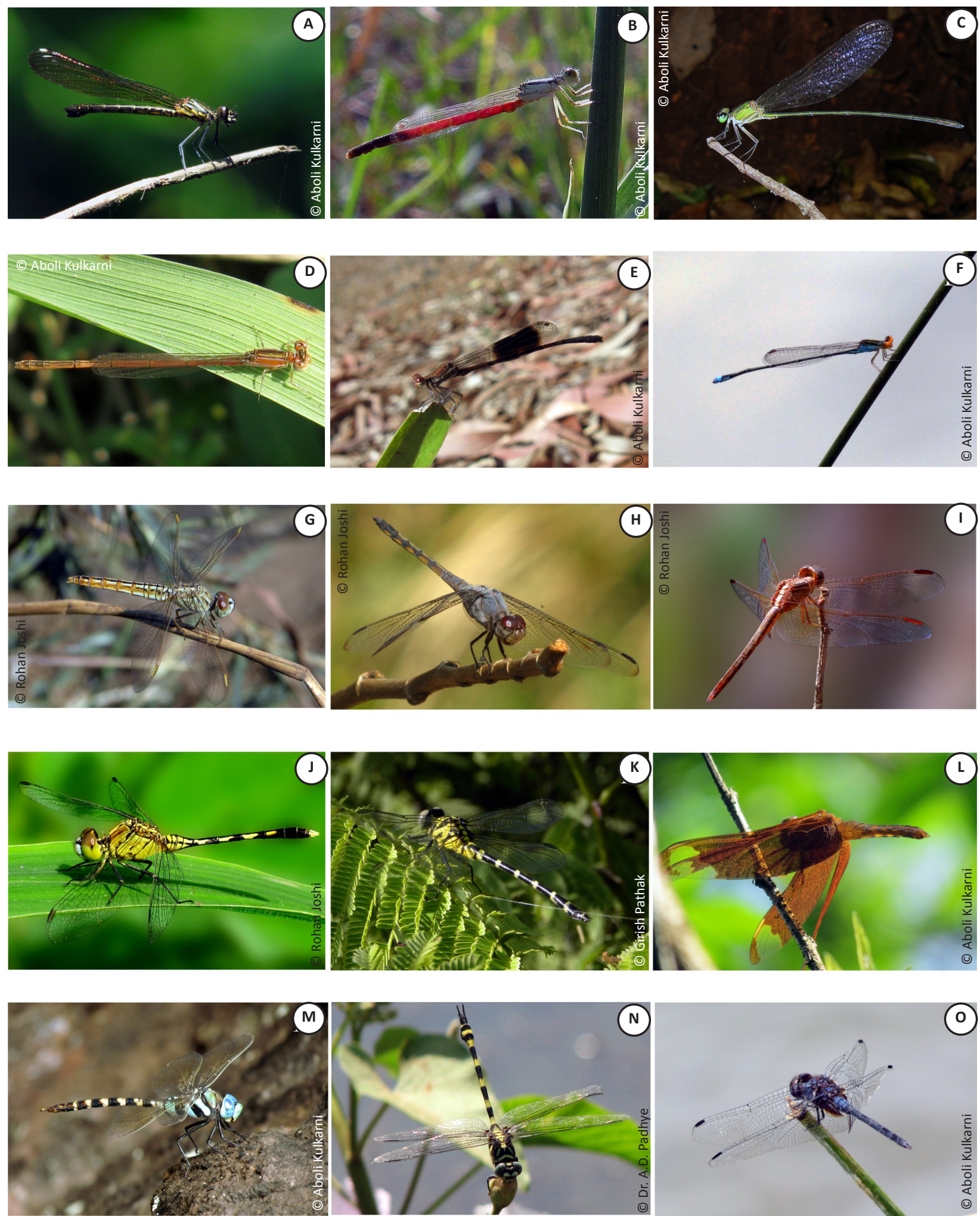

(-)

Appendix 1. Some of the damselflies and dragonflies photographed from the study sites.

A - Rhinocypha bisignata; B - Rhodischnura nursei; C - Vestalis gracilis; D - Coenagrion dyeri; E - Disparoneura quadrimaculata;

F - Pseudagrion rubriceps; G - Brachythemis contaminata; H - Potamarcha congener; I - Neurothemis intermedia; J - Diplacodes trivialis;

K - Microgomphus torquatus; L - Neurothemis fulvia; M - Anax immaculifrons; N - Ictinogomphus rapax; $\mathrm{O}$ - Trithemis festiva 
Appendix 2. Checklist of Odonata of Pune

\begin{tabular}{|c|c|c|c|c|c|}
\hline & Order & Family & Species & Remarks & Reference \\
\hline 1 & Zygoptera & Calycopterigidae & Vestalis apicalis Selys, 1873 & $*$ & \\
\hline 2 & Zygoptera & Calycopterigidae & Vestalis gracilis (Rambur, 1842) & * & \\
\hline 3 & Zygoptera & Chlorocyphidae & Libellago lineata (Burmeister, 1839) & $* * *$ & Prasad (1996) \\
\hline 4 & Zygoptera & Chlorocyphidae & Rhinocypha bisignata Hagen in Selys, 1853 & * & \\
\hline 5 & Zygoptera & Coenagrionidae & Aciagrion occidentale Laidlaw, 1919 & $* * *$ & Prasad (1996) \\
\hline 6 & Zygoptera & Coenagrionidae & Aciagrion pallidium Selys, 1891 & $* * *$ & Fraser (1933) \\
\hline 7 & Zygoptera & Coenagrionidae & Aciagrion hisopa (Selys, 1876) & $* * *$ & Fraser (1933) \\
\hline 8 & Zygoptera & Coenagrionidae & Agriocnemis femina (Brauer, 1868) & $* * *$ & Prasad (1996) \\
\hline 9 & Zygoptera & Coenagrionidae & Agriocnemis pygmea (Rambur, 1842) & $*$ & \\
\hline 10 & Zygoptera & Coenagrionidae & Ceriagrion rubiae Laidlaw, 1916 & $* * *$ & Fraser (1933) \\
\hline 11 & Zygoptera & Coenagrionidae & Ceriagrion coromandelianum (Fabricius, 1798) & * & \\
\hline 12 & Zygoptera & Coenagrionidae & Ceriagrion olivaceum Laidlaw, 1914 & * & \\
\hline 13 & Zygoptera & Coenagrionidae & Coenagrion dyeri (Fraser, 1924) & * & \\
\hline 14 & Zygoptera & Coenagrionidae & Ischnura aurora (Brauer, 1865) & $*$ & \\
\hline 15 & Zygoptera & Coenagrionidae & Ischnura senegalensis (Rambur, 1842) & * & \\
\hline 16 & Zygoptera & Coenagrionidae & Pseudagrion decorum (Rambur, 1842) & * & \\
\hline 17 & Zygoptera & Coenagrionidae & Pseudagrion indicum Fraser, 1924 & * & \\
\hline 18 & Zygoptera & Coenagrionidae & Pseudagrion microcephalum (Rambur, 1842) & * & \\
\hline 19 & Zygoptera & Coenagrionidae & Pseudagrion rubriceps Selys, 1876 & $*$ & \\
\hline 20 & Zygoptera & Coenagrionidae & Psudagrion microcephalum (Rambur, 1842) & $*$ & \\
\hline 21 & Zygoptera & Coenagrionidae & Rhodischnura nursei (Morton, 1907) & * & \\
\hline 22 & Zygoptera & Lestidae & Lestes elatus Hagen in Selys, 1862 & * & \\
\hline 23 & Zygoptera & Platycnemididae & Copera migrinipes (Rambur, 1842) & $* *$ & \\
\hline 24 & Zygoptera & Protoneuridae & Disparoneura quadrimaculata (Rambur, 1842) & $*$ & \\
\hline 25 & Anisoptera & Aeshnidae & Anaciaeschna jaspidea (Burmeister, 1839) & $* * *$ & Fraser (1936) \\
\hline 26 & Anisoptera & Aeshnidae & Anax guttatus (Burmeister, 1839) & $* * *$ & Prasad (1996) \\
\hline 27 & Anisoptera & Aeshnidae & Anax immaculifrons Rambur, 1842 & $*$ & \\
\hline 28 & Anisoptera & Aeshnidae & Gynacantha bayadera Selys, 1854 & $* *$ & \\
\hline 29 & Anisoptera & Aeshnidae & Gynacantha dravida Lieftinck, 1960 & $* *$ & \\
\hline 30 & Anisoptera & Aeshnidae & Hemianax ephippiger (Burmeister, 1839) & $* * *$ & Fraser (1936) \\
\hline 31 & Anisoptera & Cordullidae & Epopthalmia vittata Burmeister, 1839 & $* * *$ & Fraser (1936) \\
\hline 32 & Anisoptera & Gomphidae & Burmagomphus pyramidalis Laidlaw, 1922 & $* * *$ & Fraser (1934) \\
\hline 33 & Anisoptera & Gomphidae & Cyclogomphus heterostylus Selys, 1854 & $* * *$ & Fraser (1934) \\
\hline 34 & Anisoptera & Gomphidae & Cyclogomphus vesiculosus Selys, 1873 & $* * *$ & Fraser (1934) \\
\hline 35 & Anisoptera & Gomphidae & Cyclogomphus ypsilon Selys, 1854 & $* * *$ & Fraser (1934) \\
\hline 36 & Anisoptera & Gomphidae & Cyclogomphus wilkinsi Fraser, 1926 & $* * *$ & Prasad (1996) \\
\hline 37 & Anisoptera & Gomphidae & Gomphidia T-nigrum Selys, 1854 & $* * *$ & Fraser (1934) \\
\hline 38 & Anisoptera & Gomphidae & Ictinogomphus rapax (Rambur, 1842) & $*$ & \\
\hline 39 & Anisoptera & Gomphidae & Macrogomphus annulatus (Selys, 1854) & $* * *$ & $\begin{array}{l}\text { Fraser (1934); } \\
\text { Prasad (1996) }\end{array}$ \\
\hline 40 & Anisoptera & Gomphidae & Microgomphus torquatus (Selys, 1854) & $*$ & \\
\hline 41 & Anisoptera & Gomphidae & Paragomphus lineatus (Selys, 1850) & $* *$ & \\
\hline 42 & Anisoptera & Libellulidae & Acisoma panorpoides Rambur, 1842 & $* *$ & \\
\hline 43 & Anisoptera & Libellulidae & Brachydiplax sorbina (Rambur, 1842) & * & \\
\hline 44 & Anisoptera & Libellulidae & Brachythemis contaminata (Fabricius, 1793) & * & \\
\hline
\end{tabular}




\begin{tabular}{|c|c|c|c|c|c|}
\hline & Order & Family & Species & Remarks & Reference \\
\hline 45 & Anisoptera & Libellulidae & Bradinopyga geminata (Rambur, 1842) & $*$ & \\
\hline 46 & Anisoptera & Libellulidae & Crocothemis servilia (Drury, 1770) & * & \\
\hline 47 & Anisoptera & Libellulidae & Diplacodes trivialis (Rambur, 1842) & * & \\
\hline 48 & Anisoptera & Libellulidae & Neurothemis fulvia (Drury, 1773) & $*$ & \\
\hline 49 & Anisoptera & Libellulidae & Neurothemis intermedia (Rambur, 1842) & $* *$ & \\
\hline 50 & Anisoptera & Libellulidae & Orthetrum anceps (Schneider, 1845) & $* * *$ & Prasad (1996) \\
\hline 51 & Anisoptera & Libellulidae & Orthetrum chrysis (Selys, 1891) & $* *$ & \\
\hline 52 & Anisoptera & Libellulidae & Orthetrum glaucum (Brauer, 1865) & $*$ & \\
\hline 53 & Anisoptera & Libellulidae & Orthetrum luzonicum (Brauer, 1868) & * & \\
\hline 54 & Anisoptera & Libellulidae & Orthetrum pruinosum (Burmeister, 1839) & $*$ & \\
\hline 55 & Anisoptera & Libellulidae & Orthetrum sabina (Drury, 1770) & * & \\
\hline 56 & Anisoptera & Libellulidae & Orthetrum taeniolatum (Schneider, 1845) & * & \\
\hline 57 & Anisoptera & Libellulidae & Pantala flavescens (Fabricius, 1798) & * & \\
\hline 58 & Anisoptera & Libellulidae & Potamarcha congener (Rambur, 1842) & * & \\
\hline 59 & Anisoptera & Libellulidae & Rhyothemis variegata (Linnaeus, 1763) & $*$ & \\
\hline 60 & Anisoptera & Libellulidae & Sympetrum fonscolumbi (Selys, 1840) & * & \\
\hline 61 & Anisoptera & Libellulidae & Tholymis tillagra (Fabricius, 1798) & $* *$ & \\
\hline 62 & Anisoptera & Libellulidae & Tramea basiliaris (Palisot de Beauvois, 1805) & * & \\
\hline 63 & Anisoptera & Libellulidae & Trithemis aurora (Burmeister, 1839) & * & \\
\hline 64 & Anisoptera & Libellulidae & Trithemis festiva (Rambur, 1842) & * & \\
\hline 65 & Anisoptera & Libellulidae & Trithemis kirbyi Selys, 1891 & $*$ & \\
\hline 66 & Anisoptera & Libellulidae & Trithemis pallidinervis (Kirby, 1889) & * & \\
\hline 67 & Anisoptera & Libellulidae & Urothemis signata (Rambur, 1842) & $* * *$ & Fraser (1936) \\
\hline 68 & Anisoptera & Libellulidae & Zyxomma petiolatum (Rambur, 1842) & $* * *$ & Fraser (1936) \\
\hline 69 & Anisoptera & Macromidae & Macromia cingulata Rambur, 1842 & $* * *$ & Fraser (1936) \\
\hline 70 & Anisoptera & Macromidae & Macromia flavicincta Selys, 1874 & $* * *$ & Fraser (1936) \\
\hline
\end{tabular}

* - Observed in transects; ${ }^{* *}$ - Observed outside transects; ${ }^{* * *}$ - Previous records

Prasad, M. (1996). An account of the Odonata of Maharashtra State, India. Records of Zoological Survey of India 95(3-4): 305-327.

Samways, M.J. (1992). Dragonfly conservation in South Africa: a biogeographic perspective. Odonatologica 21(2): 165-180.

Samways, M.J. \& N.S. Steytler (1996). Dragonfly (Odonata) Distribution Patterns In Urban and Forest Landscapes and Recommendations for Riparian Management, Biological Conservation 3207(96): 279-288; http://dx.doi.org/10.1016/S0006-3207(96)00032-8

Saunders, D.L., J.J. Meeuwig \& A.C.J. Vincent (2002). Freshwater protected areas: strategies for conservation. Conservation Biology 16(1): 30-41; http://dx.doi.org/10.1046/j.1523-1739.2002.99562.x

Subramanian, K.A. (2009). Damselflies and Dragonflies of Peninsular India - A Field Guide. Vigyan Prasar, Department of Science and Technology, India, 118pp.

Subramanian, K.A. (2010). Report on biodiversity and status of riverine ecosystems of the Western Ghats. Western Ghats Ecology Expert Panel. <http://westernghatsindia.org/commissioned-papers> Accessed on 10 July 2012.

Subramanian K.A., S. Ali \& T.V. Ramachandra (2008). Odonata as indicators of riparian ecosystem health a case study from south western Karnataka, India. Fraseria 7: 83-95.
Subramanian, K.A. \& S.S. Talmale (2010). Insect in UrbanIndustrial Landscapes: A Case Study on Odonata and Lepidoptera (Rhopalocera: Insecta) diversity of Pimpri-Chinchwad Muncipality, Maharashtra. Proceedings: Impact of Climate Change on Biodiversity and Challenges in Thar Desert. Desert Regional Centre, Zoological Survey of India, Jodhpur, 73-78pp.

Subramanian, K.A., F. Kakkassery \& M.V. Nair (2011). The status and distribution of dragonflies and damselflies (Odonata) of the Western Ghats, pp. 63-72. In: Molur, S., K.G. Smith, B.A. Daniel \& W.R.T. Darwall (comp.). The Status and Distribution of Freshwater Biodversity in the Western Ghats, India. IUCN, Cambridge, UK and Glad, Switzerland and Zoo Outreach Organization, Coimbatore, India.

Wagh, G.K. \& H.V. Ghate (2002). Freshwater fish fauna of rivers Mula and Mutha, Pune, Maharashtra. Zoos' Print Journal 18(1): 977-981; http://dx.doi.org/10.11609/JoTT.ZPJ.18.1.977-81

World Conservation Monitoring Centre (WCMC) (2000). Global Biodiversity: Earth's living resources in the $21^{\text {st }}$ Century. By: B. Groombridge and M.D. Jenkins, World Conservation Press, Cambridge, UK. 